Volume 13(1), 2019

Page: 21-40

\title{
Determinants of Tabarru' Fund Proportion In Family Takaful in Indonesia
}

\author{
Siti Ulviatul Arofahํㅡ, Novi Puspitasari², Lilik Farida ${ }^{3}$
}

\begin{abstract}
This paper aims to analyze the determinants of the proportion of tabarru'fund in family takaful in Indonesia at the periods 2012 - 2016. Insurance growth reach 75\% which $60 \%$ came from family takaful. Family takaful implements separation on fund management. Fund management with fund separation is in line with Shariah Split Fund Theory which in practice requires proportion. The method used in the research data is panel data regression. The independent variables of this study are claims $\left(C_{i t}\right)$, retakaful $\left(R T_{i t}\right)$, commission fees $\left(C F_{i t}\right)$, and administrative and general expenses $\left(A G_{i t}\right)$. The dependent variable of this study is the proportion of tabarru'fund $\left(T_{i t}\right)$. The sample was chosen by using purposive sampling method and obtained sample member as many as 15 companies of Takaful. The results of this study indicate that claims affect the proportion of tabarru' fund and these variables as determinant of tabarru' fund proportion. While retakaful have not positive effect on the proportion of tabarru' fund, and then commission fees and administrative and general expenses have not negative effect on the proportion of tabarru' fund.
\end{abstract}

Keywords: Family Takaful, Sharia Split Fund Theory, Tabarru' Fund

Abstrak. Penelitian ini bertujuan untuk menganalisis determinan proporsi dana tabarru' pada asuransi jiwa syariah (takaful keluarga) di Indonesia pada periode 2012-2016. Pertumbuhan asuransi syariah ini mencapai $75 \%$, dimana $60 \%$ didominasi oleh takaful keluarga. Dalam pengelolaan dana, asuransi jiwa syariah menerapkan pemisahan dana. Pemisahan dana ini sejalan dengan Shariah Split Fund Theory yang dalam prakteknya memerlukan proporsi. Metode yang digunakan dalam menganalisis data adalah regresi panel data. Variabel independen dari penelitian ini adalah klaim $\left(C_{i t}\right)$, retakaful $\left(R T_{i t}\right)$, biaya komisi $\left(C F_{i t}\right)$, dan biaya administrasi dan umum $\left(A G_{i t}\right)$. Variabel dependen dari penelitian ini adalah proporsi dana tabarru' $\left(T_{i t}\right)$. Sampel dipilih dengan menggunakan metode purposive sampling dan diperoleh sampel sebanyak 15 perusahaan asuransi jiwa syariah. Data penelitian diolah dengan analisis regresi panel data. Hasil penelitian ini menunjukkan bahwa klaim memengaruhi proporsi dana tabarru' dan variabel ini sebagai penentu proporsi dana tabarru'. Sedangkan retakaful tidak berpengaruh positif pada proporsi dana tabarru' dan biaya komisi serta biaya administrasi dan umum tidak berpengaruh secara negatif pada proporsi dana tabarru'.

Kata kunci : Asuransi Jiwa Syariah, Dana Tabarru', Sharia Split Fund Theory

\footnotetext{
${ }^{1}$ Fakultas Ekonomi dan Bisnis Universitas Jember | siviaa9@gmail.com ${ }^{2}$ Fakultas Ekonomi dan Bisnis Universitas Jember | vie.salva@yahoo.com

${ }^{3}$ Fakultas Ekonomi dan Bisnis Universitas Jember | lilikfarida123@gmail.com
} 


\section{Introduction}

Since 2010 as stipulated in PMK Number 18/PMK.010/2010, Takaful implements separation of fund in its financial management. The companies separate the assets and liabilities of the tabarru' fund with the assets and liabilities of the company. According to Puspitasari (2016) separation of fund in this context is the separation of assets and liabilities of tabarru' fund from corporate fund. This is an insurance effort to avoid the element of maisir, gharar, and riba.

The practice of separation fund between participant fund and corporate fund aims to get halal in muamalah relation. This separation of fund is in line with the theory of Shariah split fund theory. This concept focuses on financial management with the separation of fund and the distribution of welfare whose accountability is accountable to God, man, and nature (Puspitasari, 2015: 173).

Studies on the basis of determinant of tabarru' fund is still limited. The focus of this study is sharia life insurance. Previous research has mentioned that the variables of claims, retakaful, commission fees and administrative and general expenses affect the proportion of tabarru' fund in sharia general insurance companies. Meanwhile, this research tries to re-examine but on different object that is on sharia life insurance. Previous research has contributed that there was several factors that determine tabaru fund. Puspitasari (2012) stated that claim, retakaful, and internal financial of the company affect the proportion of tabarru' fund and their ujrah on sharia general insurance. If the composition of the tabarru' fund with the ujrah fund is not in a good and ideal position, then it will affect the ownership of each asset and the financial performance of the Sharia life insurance company.

Purwocaroko and Suprayogi (2016) had stated that the ideal composition of tabarru' fund and ujrah fund by Dynamic Financial Analysis method in sharia life insurance company has $68.73 \%: 31.27 \%$, this composition is influenced by claims, retakaful, and internal finance of the company. While, this research study the determinants of the tabaru' fund using panel data 
regression. Another study by Puspitasari (2016) stated that four variables that significantly influence the proportion of tabarru' fund are claims, reinsurance activities, commission fees, and administrative and general expenses.

Previous research studied sharia general insurance companies. Both types of Islamic insurance; sharia general insurance and sharia life insurance have different characteristics. Puspitasari (2016) stated that Sharia general insurance has a short membership period (approximately one year) while in sharia life insurance has a longer membership period (approximately ten years). Plus also with the investment fund participants on sharia life insurance (PMK number 18/PMK.010/2010).

Therefore, this paper is intended to analyze the factors influencing the proportion of tabarru' fund on family takaful in Indonesia. It is important to be analyzed, so that family takaful can determine the proportion of tabarru'fund properly because the insurance company as the operator of management tabarru' fund must show professionalism in work. This study aims to analyze: (1) the effect of claims on the proportion of tabarru' fund, (2) the effect of retakaful on the proportion of tabarru' fund, (3) the effect of commission fees on the proportion of tabarru'fund, (4) the effect of administrative and general expenses against the proportion of tabarru' fund on family takaful in Indonesia.

\section{Literature Review}

\section{Shariah Split Fund Theory}

The practice of tabarru' fund separation with ujrah (fee) fund is in line with the theory concept of Shariah Split Fund Theory. This theory is a concept of financial management with the separation of fund and the distribution of welfare whose accountability can be accountable to God, human, and nature based on the value of justice, honesty, and transparency. Welfare-sharing accountability in Shariah Split Fund Theory concept concerns accountability of welfare division that can be accounted to stakeholders, that is Allah SWT, human and nature (Puspitasari, 2015: 175-176). 


\section{Tabarru' Fund}

Tabarru' fund is a collection of fund used to help each other among participants. The contract used is akad tabarru' (PMK number 18 of 2010). Previously, tabarru' is part of the grant agreement (the DSN MUI Fatwa No.53/DSN-MUI/III/2006). DSN MUI has arranged fund management used akad tabarru' on Takaful business. Fund management tabarru' must follow the rules of the DSN MUI, namely: (1) book of tabarru' fund must be separated from other fund; (2) the investment proceeds from tabarru' fund into collective rights of the participant and recorded in tabarru' account; (3) from the investment proceeds, the insurance company may obtain profit sharing based on mudharabah contract or mudharabah musyarakah agreement, or obtain ujrah (fee) based on wakalah bil ujrah.

It is mentioned in Regulation of the Minister of Finance No. 18/2010 that the assets and liabilities of tabarru' fund represent the collective assets and liabilities of the participants. Companies are required to use tabarru' fund only to: (a). Payment of compensation to participants having problems or other eligible parties; (b). Reinsurance payments; (c). Qardh repayment to the company; and/or (d). Tabarru' refund due to policy cancellation within the allowed period.

DSN MUI explained in the fatwa no. 53/DSN-MUI/III/2006 that tabarru' fund in takaful is a fund to help each other among fellow customers, should not be tariff fund. The tariff fund in practice, for example, that is used for the company's operational costs or even claimed to be the company's profit. Tabarru' fund should be used only for everything directly related to the interest of customers, such as claims, tabarru reserves, and Islamic reinsurance (Puspitasari, 2015: 92). The statement is in line with the statement of Rahman and Mohammad (2010) stated that fund from the tabarru' fund account are used to a disaster strikes one of the participants within the period of the agreement. For example, if a participant is unfortunate then the participant will receive financial aid from a tabarru' fund account or if the participant dies, 
his/her family will receive financial compensation derived from the tabarru' fund account.

At least, there are three things that affect the tabarru' fund in Purwocaroko and Suprayogi (2016). They are claim, retakaful, and internal corporate finance aspects. Claim is a request of mortgage by takaful participant to takaful company for contribution which has been paid during the period. Insurance claim is one of the variables that support to change amount of tabarru' fund exist (Purwocaroko and Suprayogi, 2016). Tabarru' fund collection and investment proceeds are used for claims fee (Takaful benefit), reinsurance, and so on (Sumanto et al, 2009: 97). Growth of insurance is one cause of premium paid by the policy holder. The determination of the ideal premium rate is the tariff that must cover the claims as well as the various insurance and profit costs of the company.

Meanwhile, the definition of retakaful is not much different from reinsurance, which to reinsert a insurance. The purpose of the retakaful is to reduce and minimize the burden of risk received by the company (Puspitasari, 2015: 197). This is in line with Fiegenbaum and Thomas's (1990) statement, the proper selection of reinsurance may improve underwriting performance, primarily in relation to the spreading of risks.Next, internal Corporate Finance Aspects. Internal finance company is the cost used to finance the company's operations in managing the fund participants. One of the operational costs of the company that contributes to tabarru' fund is the commission fees and administrative and general expenses. The commission fee is the cost associated with marketing by the company. The commission fee is paid to the broker who is marketing the products of the company. Meanwhile, administrative and general expenses are costs incurred by companies relating to the company's operating costs, such as employee salary payments, purchases of office equipment and equipment, and others.

Based on previous theoretical and research reviews, it is stated that in Takaful Insurance implements the separation of fund (PMK Number 18/PMK.010/2010). The Company shall separate the assets and liabilities of the 
tabarru' fund with the assets and liabilities of the company. The concept of Shariah split fund theory is in line with it, namely the concept of financial management with the separation of fund and the distribution of welfare whose accountability can be accountable to God, human, and nature based on fairness, honesty and transparency.Thus the conceptual framework of this study can be arranged as in Figure 1.

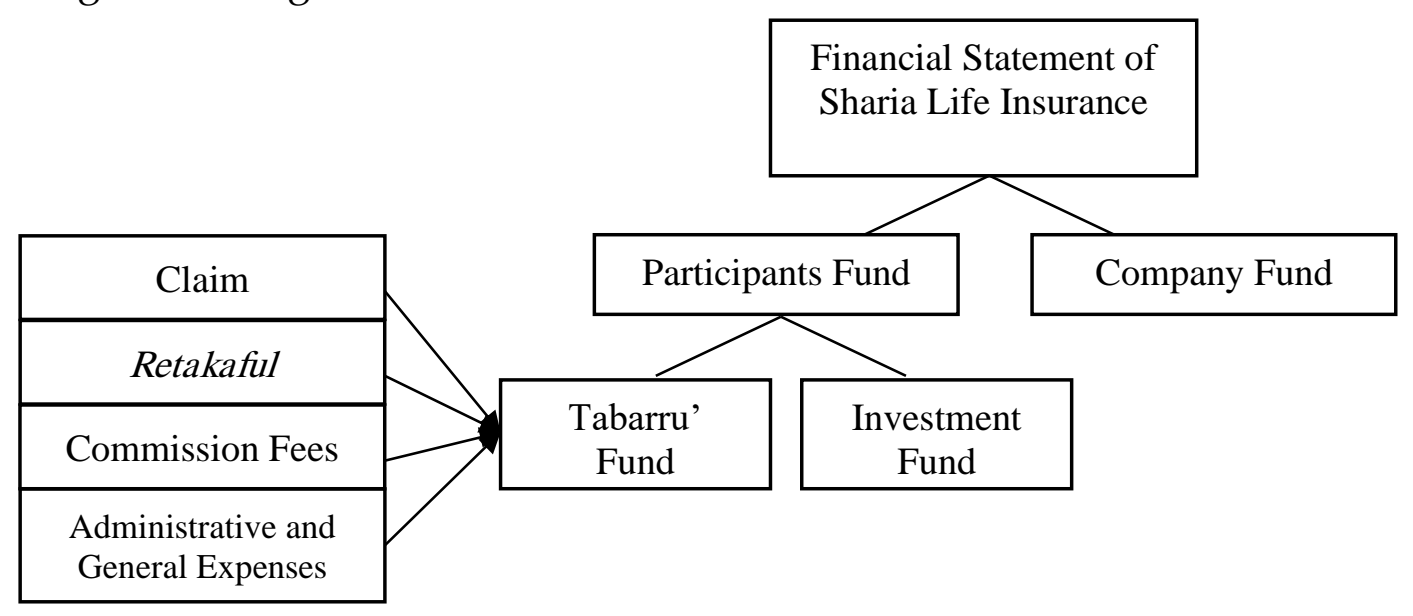

Figure1. Conceptual Framework

\section{Method}

The research is quantitative research. The population is Sharia Life Insurance Company which registered in the Financial Services Authority within the period of 2012 - 2016. The method used to take samples on the research that is purposive sampling. The criterias of the samples are:

First, Family Takaful (Sharia life insurance companies and sharia unit life insurance companies) actively and consistently publish their annual financial statements within the period of 2012 - 2016;

Second, Family Takaful (Sharia life insurance companies and sharia unit life insurance companies) that has done the concept of separation of fund according to Regulation of the Minister of Finance.

The sample are consits takaful family company and unit takaful family company. They are PT Asuransi Jiwa Amanah Jiwa Giri Artha, PT Asuransi Jiwa Syariah Al-Amin, PT Asuransi Takaful Keluarga, PT AIA Financial (sharia 
unit), PT Asuransi Allianz Life Indonesia (sharia unit), PT AXA Financial Indonesia (sharia unit), PT AXA Mandiri Financial Services (sharia unit), PT Asuransi Jiwa Central Asia Raya (sharia unit), PT Great Eastren Life Indonesia (sharia unit), PT Asuransi Jiwa Manulife Indonesia (sharia unit), PT Prudential Life Assurance (sharia unit), PT Asuransi Simas Jiwa (sharia unit), PT Panin Dai-Ichi Life, PT Sun Life Financial Indonesia, and PT Tokio Marine Life Insurance Indonesia (sharia unit).

The operational definition and measurement of the research variables are summarized in Table 1.

Table 1. Definitions of Variable Operations and Measurements

\begin{tabular}{|c|c|c|c|}
\hline Variables & Definition & Measurement & Scale \\
\hline \multirow{2}{*}{$\begin{array}{l}\text { Tabarru' fund } \\
\text { Proportion }\end{array}$} & \multirow{2}{*}{$\begin{array}{l}\text { a pool of fund used to help } \\
\text { rescue participants }\end{array}$} & tabarru'fund & \multirow[t]{2}{*}{ Ratio } \\
\hline & & $\overline{\text { contribution Bruto }}$ & \\
\hline \multirow[t]{2}{*}{ Claim } & Amount of kindness fund & Claim & \multirow[t]{2}{*}{ Ratio } \\
\hline & $\begin{array}{l}\text { donated to participants at } \\
\text { risk }\end{array}$ & $\overline{\text { Contribution Bruto }}$ & \\
\hline \multirow{2}{*}{$\begin{array}{l}\text { Retakaful } \\
\text { Contribution }\end{array}$} & A number of charitable fund & Retakaful & \multirow[t]{2}{*}{ Ratio } \\
\hline & $\begin{array}{l}\text { donated to participants at } \\
\text { risk }\end{array}$ & $\overline{\text { Contribution Bruto }}$ & \\
\hline \multirow{2}{*}{$\begin{array}{l}\text { Commission } \\
\text { Fees }\end{array}$} & marketing costs given to & biayakomisi & \multirow[t]{2}{*}{ Ratio } \\
\hline & $\begin{array}{l}\text { brokers who market the } \\
\text { products of sharia life } \\
\text { insurance companies }\end{array}$ & $\overline{\text { Contribution Bruto }}$ & \\
\hline \multirow{2}{*}{$\begin{array}{l}\text { Administrative } \\
\text { and General } \\
\text { Expenses }\end{array}$} & Operational costs incurred & administration and general exp & \multirow[t]{2}{*}{ Ratio } \\
\hline & $\begin{array}{l}\text { by the company in carrying } \\
\text { out its business activities } \\
\text { include employee salaries, } \\
\text { water charges and other } \\
\text { charges }\end{array}$ & Contribution Bruto & \\
\hline
\end{tabular}

This research used panel data regression to analyze the factors that affect the tabarru' fund proportion on takaful family. This research have several hypothesis, as follows:

\section{Relationship of Claim with Proportion of Tabarru' Fund}

Claim is a compensation activity to participants who are experiencing at risk (Puspitasari, 2016). Claim is a request of mortgage by insurance participant to insurance company for contribution which has been paid during the period. 
Any fund is related to need of participants are grouped into a pool of tabarru' fund. Claim insurance participant is one of the variables that strongly support the changing amount of tabarru' fund existing (Puspitasari, 2011b). Based on the results of previous research, it can be prepared research hypothesis as follows:

\section{$\mathrm{H}_{1}$ : Claims have a positive effect on the proportion of tabarru' fund}

\section{Relationship of Retakaful with Proportion of Tabarru' Fund}

As in general sharia insurance, sharia life insurance also undertakes retakaful reduce or share some risk to other party in this case reinsurance companies. This retakaful is conducted by the company as an effort to tackle the risks that may occur to the participants. This retakaful by the operator of the insurance company is manifested by the payment of the retakaful contribution. This activity is the right of participants so that fundto the payment of retakaful contributions are taken from the pool of tabarru' fund. Tabarru' fund should be used for everything directly only related to the interests of customers, such as claims, tabarru reserves, and Islamic reinsurance (Puspitasari, 2015: 92). Based on the results of previous research, it can be prepared research hypothesis as follows:

\section{$\mathrm{H}_{2}$ : Retakaful has a positive effect on the proportion of tabarru' fund}

\section{Relationship of Commission Costs with Tabarru' fund}

Commission fees related to marketing activities undertaken by insurance companies. This commission fee is taken from the ujrah fund provided by the participant to the insurance company as a consideration for the fund management of the participants. Ujrah fund has taken from the premium provided by the participants. Premium fund are separated as Shariah Split fund theory. The participants need to meet by using a pool of tabarru' fund, while the company's operations are filled with ujrahfund. If the cost is large, the ujrah fund to meet these costs is also large. That mean, the proportion 
of tabarru' fund is getting lower. The result of the Puspitasari's study (2016) found that the commission fee had an effect on the proportion of tabarru' fund in sharia general insurance. Thus, the research hypothesis can be prepared as follows:

$\mathrm{H}_{3}$ : Commission fees have a negative effect on the proportion of tabarru' fund

\section{Relationship BetweenAdministrative and General Expenses with Tabarru' fund}

Administrative and general expenses are costs incurred by companies relating to the company's operating costs, such as payrolls, purchases of office equipment and supplies, and more. The higher the administrative and general burden, the need for ujrah fund will be high and cause the proportion of tabarru' fund lower. As commission fees, administrative expenses andcommonly associated with ujrah fund. The result of Puspitasari (2016) research indicated that the administrative and general expenses affect the proportion of tabarru' fund in sharia general insurance. Thus can be arranged hypothesis as follows:

$\mathrm{H}_{4}$ : Administrative and general expenses have a negative affect on the proportion of tabarru' fund

The panel data regression model that will be used in this study is the general form of regression as follows:

$T_{i t}=a+b_{1} C_{i t}+b_{2} R T_{i t}-b_{3} C F_{i t}-b_{4} A G_{i t}+e_{i t}$

Thus the model equation of this study is as follows, where:

$T_{i t} \quad=$ Tabarru' fund $i$ at period $t$

$a \quad=$ Intercept panel data regression

$b_{1}-b_{4}=$ Coefficient variable of the estimator $i$ at period $t$

$C_{i t} \quad=$ Variable claim $i$ at period $t$

$R T_{i t} \quad=$ Variable retakaful $i$ at period $t$

$C F_{i t}=$ Variable commision fees $i$ at period $t$

$A G_{i t}=$ Variable administrative and general expenses $i$ at period $t$

$e_{i t}=$ error 


\section{Result and Discussion}

The statistical descriptions of the research data are summarized in Table 2. The results of the data analysis show that the tabarru' fund variable has an average value of $113.66 \%$ and a standard deviation of $312.23 \%$. This means that the average value is smaller than the standard deviation value so it indicates that the spread data is not close to the average value. The minimum value is $2.85 \%$ and the maximum value is $2502.99 \%$. These results indicate that the tabarru' fund applied by the company have a big difference.

The claim variable has an average value of $71.26 \%$ and a standard deviation of $350.93 \%$. This means that the average value is smaller than the standard deviation value, so it indicates that the spread data is not close to the average value. The standard deviation value of $350.93 \%$ indicates that the data deviation is high, ie 5 times the average value. The minimum value is $0.85 \%$ and the maximum value is $2972.88 \%$. These results indicate that the claims in each company have a big difference. This shows the number of participants and risks borne by the company vary, so the payment of claims between companies experienced a significant difference.

The retakaful variable has an average value of $19.09 \%$ and a standard deviation of $30.72 \%$. The standard deviation value is greater when compared to the average value. This means that the spread data is not close to the average value. The minimum value is $0.40 \%$ and the maximum value is $239.79 \%$. These results indicate that the retakaful in each company is different. The risk profile received by each company is different. Companies with maximum value on the part of the retakaful have participants who insure the high risk, so it takes $239.79 \%$ of its bruto contribution.

Commission fees have an average value of $41.08 \%$ and a standard deviation of $29.79 \%$. This result shows the standard deviation value is smaller than the average value, thus indicating that the data is good enough and the 
data is not spread. This shows that each company has expenses for commission fees are almost the same. The minimum value is $1.28 \%$ and the maximum value is $142.72 \%$. This shows that the costing of commissions for each company is different. Companies with low commission fees indicate that the company maximizes the company's internal marketing capabilities. Meanwhile, companies with high commission fees indicate that companies spend high fund to pay for insurance brokers.

Administrative and general expenses variables have an average value of $287.76 \%$ and a standard deviation of $1458.42 \%$. This means that the standard deviation value is 5 times higher than the average value, thus indicating that the spread data is not close to the average. The minimum value is $0.52 \%$ and the maximum value is $12180.00 \%$. This shows that there are significant differences in the determination of administrative and general expenses on each company. The company that have maximum value need large expenditure to general and administrative expenses, which means that the company has a large number of employees and other administrative activities in companies that have the maximum value in this variable.

Table 2. Statistics Description

\begin{tabular}{lrrrr}
\hline \multicolumn{1}{c}{ Variables } & Minimum & Maximum & Average & $\begin{array}{r}\text { Standard } \\
\text { Deviation }\end{array}$ \\
\hline Tabarru' fund (\%) & 2,85 & 2502,99 & 113,66 & 312,23 \\
Claim (\%) & 0,85 & 2972,88 & 71,26 & 350,93 \\
Retakaful (\%) & 0,40 & 239,79 & 19,09 & 30,73 \\
Commission Fees (\%) & 1,28 & 142,72 & 41,08 & 29,79 \\
Administration and General & 0,52 & 12180,00 & 287,76 & 1458,42 \\
Expenses \% & & & & \\
\hline
\end{tabular}

This analysis is done after the data is normally distributed. Panel data regression analysis is used for testing linear relationships between two or more independent variables on one dependent variable and its data is panel data. Variable dependent in this research is proportion of tabarru' fund. Meanwhile, variable independent is claim, retakaful, commission fees, and administrative 
and general expenses. The results of panel data regression analysis are presented in Table 3.

Table 3. The Result of Panel data regression Test

\begin{tabular}{lccc}
\hline \multicolumn{1}{c}{ Independent Variable } & Coefisient & $\boldsymbol{t}$-value & $\boldsymbol{\rho}$-value \\
\hline Constanta & 0,052 & 0,360 & \\
Claim & 0,843 & 20,007 & 0,000 \\
Retakaful & $-0,117$ & $-0,241$ & 0,810 \\
Commission Costs & 0,272 & 1,137 & 0,260 \\
Administrative and General Expenses & 0,242 & 11,799 & 0,000 \\
\hline
\end{tabular}

Based on the results of panel data regression analysis presented in Table 3 , the equation of the regression model is obtained as follows:

$$
T_{i t}=0,052+0,843 C_{i t}-0,117 R T_{i t}+0,272 C F_{i t}+0,242 A G_{i t}+e_{i t} \text { (Eq. 2) }
$$

This data has been through several stages to get the Best Linear model of Unbiased Estimation (BLUE), including data normality test and classical assumption test consisting of multicollinearity test, heteroscedasticity test, and autocorrelation test. There is interruption in the BLUE model, but all have been fixed in accordance with the repair technique. Autocorrelation infected the research and repaired by choccrane orcutt method. The result of the repairment is presented in Table 4.

Table 4. Result of Autocorrelation Test

\begin{tabular}{ccccccc}
\hline $\mathbf{N}$ & $\mathrm{DW}$ & $\mathrm{dL}$ & $\mathrm{dU}$ & 4-dL & 4-dU & Keterangan \\
\hline 75 & 1,018 & 1,363 & 1,586 & 2,637 & 2,414 & Positive autocorrelation \\
\multicolumn{7}{c}{ Result of Chocrane-Orcutt Method } \\
\hline 75 & 1,767 & 1,363 & 1,586 & 2,637 & 2,414 & No autocorrelation \\
\hline
\end{tabular}

The results of hypothesis test with t-test based on the final model of some corrective actions are shown in Table 5.Based on Table 5, it can be seen that there is only one variable whose hypothesis is accepted is claims variable. This showed that the claim variable has a positive effect on the proportion of 
tabarru' fund. An increase in funding for claims will be followed by an increase in the proportion of tabarru' fund. Meanwhile, the other three hypotheses are accepted which means there is no positive effect of retakaful variables, and there is no negative affect of commission fees and administrative and general expenses on the proportion of tabarru' fund in family takaful.

Table 5 Results of $\mathbf{t}$-test

\begin{tabular}{llcc}
\hline \multirow{2}{*}{ Independen Variables } & \multicolumn{2}{c}{$\rho$-value } & \multirow{2}{*}{ Explanation } \\
\cline { 2 - 3 } & 2 side & 1 side & \\
\hline Claim & 0,000 & 0,000 & $\mathrm{H}_{\mathrm{a} 1}$ accepted \\
Retakaful & 0,973 & 0,487 & $\mathrm{H}_{\mathrm{a} 2}$ rejected \\
Commission Fees & 0,603 & 0,302 & $\mathrm{H}_{\mathrm{a} 3}$ rejected \\
Administrative and General Expenses & 0,000 & 0,000 & \\
\hline
\end{tabular}

\section{Discussion}

The object of this research is the family takaful (Sharia life insurance companies and sharia unit life insurance companies) in Indonesia which is registered in the Financial Services Authority which is actively operating in the period 2012-2016 as well as conducting separation practices in accordance with Minister of Finance Regulation Number 18/PMK.010/2010 Sharia life insurance company is an insurance company that fully runs its business according to sharia principles. While the sharia unit life insurance companies is a conventional life insurance company that has a sharia-based business unit.The population in this study were 26 companies consisting of 5 Sharia Life Insurance Companies and 21 Life Insurance Companies Sharia Business Units. Meanwhile based on sampling techniques, the sample of this study is 15 companies that publish financial statements consistently from 2012 to 2016. With the result that get 75 financial statements.

\section{The Influence of Claims on Tabarru' Fund}

The results showed that the variable claims positively affect the proportion of tabarru' fund in family takaful registered in the Financial Services Authority at the period 2012 - 2016. Based on the theoretical review, the claim payment is taken from the tabarru' fund collection as a form of helping among 
the participants to avoid the elements of maisyir, gharar, and riba through tabarru'contract at the beginning of the participants participate in insurance. The size of the claim will affect the proportion of tabarru' fund and the financial performance of the insurance company.

Claims will affect the proportion of tabarru' fund, because under Regulation of the Minister of Finance No. 182010 that the assets and liabilities of tabarru' fund represent the collective assets and liabilities of the participants. The Company shall use tabarru' fund only for the payment of compensation to the participant experiencing the problem or other eligible party; reinsurance payments; Qardh repayment to the company; and or tabarru' refund due to cancellation of the policy within the allowed period. If the claim is high, then the proportion of tabarru' fund should be high. The result of this research proves that.

This study is consistent with the results of Purwacaroko and Suprayogi research (2016) which stated that the ideal composition of tabarru'-ujrah fund is influenced by exogenous variables (independent) claims. The results of this study are also in line with the practice of sample companies that indeed collect claims from tabarru' fund collection which is evident in the financial statements of claims payment accounts in the tabarru' fund report. It is also in line with the results of Puspitasari (2016) study which stated that the claims variable is a factor influencing the proportion of tabarru' fund in sharia general insurance companies. Therefore, it can be stated that the claim is a determinant of the proportion of tabarru' fund both in general insurance sharia and sharia life insurance.

\section{The Influence of Retakaful on Tabarru' Fund}

The results showed that the retakaful variable has no effect on the proportion of tabarru' fund in family takaful registered in the Financial Services Authority. Retakaful (Islamic reinsurance) is important and it is a must when sharia general insurance companies accept the participants with the level of risk that is considered that big and the company is not able to handle it (Puspitasari, 
2016). Therefore, the retakaful is the needs of the participants and need of the participants are met by using the pool of tabarru' fund. This is in accordance with the Regulation of the Minister of Finance No. 18 of 2010 that the assets and liabilities of tabarru' fund represent the assets and obligations of the participants collectively.

Ideally, the retakaful affects the proportion of tabarru' fund, as it is one of the participants needs. However, this study was not found evidence of that. This may be due to differences in the characteristics of family takaful whereby it has characteristics that primarily provide services, protection, and assistance regarding the soul of a person with a long period of membership in general 5 years - 10 years. Therefore, life insurance companies do little of retakaful. President Director of BNP Paribas, Vivian Secakusuma stated that the longer the investment period, the smaller the risk, and vice versa the shorter the investment period the less the risk (swa.co.id). In addition, it is also mentioned in Tanata (2015: 155) that the longer the investment period, the investment risk is potentially lower.

On the other hand, with long term long term, sharia life insurance companies have a large pool of tabarru' fund, thus making the company sufficient fund to bear the risks that occur in the future or in other words risk based capital (RBC) high companies. A high RBC (risk based capital) indicates that the healthier the company's financial condition. The data shows that the average RBC of sharia life insurance companies has exceeded above the provisions of the Financial Services Authority regulation of $500 \%$ (infobanknews.com). Medium Minimum RBC Limit Life insurance companies in the regulation of the Financial Services Authority are 200\% (Regulation of the Financial Services Authority Number 69/POJK.05/2016).

In addition to the long term participation the risks involved tend to be small and the adequacy of the pool of tabarru' fund to assume risk as a possible reason for the retakaful is not the determinant of the proportion of tabarru' fund, there is another reason that the Takaful companies have membership requirements for prospective participants. In general, companies accept 
prospective participants only with a relatively young age. One of the sharia life insurance companies (PT Asuransi Takaful Keluarga) requires the age of admission plus the maximum agreement period of the participant is 56 years on Takaful Al Khairat Seri product. In Amanah Artha Pendidikan products in PT Asuransi Jiwa Amanah Jiwa GiriArtha requires maximum insurance period of participants at age 65 years. Meanwhile, Atta'min Kecelakaan Kerja is a product at PT Asuransi Jiwa Syariah Al-Amin has the provisions of the insured participant's age plus the maximum period of sharia insurance for 65 years. At this age makes the risk that may occur is small relatively, when compared with the projected life expectancy of Indonesia is around 75.4 years (bappenas.go.id). Because the views are still relaif far from the limit of life expectancy, then the company does not do retakaful.

From the above description, it can be stated that sharia life insurance companies do a retakaful if the company sees that the company is not able to bear its own risks that may occur so that companies share the risk with sharia reinsurance companies. On the other hand, companies tend to do not accept participants with a level of risk that exceeds the limits of a company's ability to protect it. This is also in accordance with the Puspitasari (2016) statement that companies are not allowed to undertake too much reinsurance (retakaful) which will lead to the impression that companies are avoiding risk. Some of the above statements consistent with the results of research which states that the retakaful has no positive affect on the proportion of tabarru' fund.

The results of this study are inconsistent with the results of Purwacaroko and Suprayogi research (2016) which states that the ideal composition of tabarru'-ujrah fund is influenced by exogenous (independent) variables in the form of retakaful. The result is not in line with the results of research Puspitasari (2016) also which states that the variable retakaful be a determinant of the proportion of tabarru' fund in the Islamic general insurance company.

\section{The Influence of Commission Fees on the Proportion of Tabarru' Fund}


The results showed that the variable cost of commission partially does not negative affect the proportion of tabarru' fund in family takaful (sharia life insurance companies and sharia unit of life insurance companies registered in the Financial Services Authority. Thus, the commission fee is not a determinant of the proportion of tabarru' fund in sharia life insurance companies and sharia unit life insurance companies. The commission fee is a requirement of the company to market its insurance products. The Company uses the services of brokers, agents, and consultant services for that matter. As a consequence, the company issues incentives to the party from the services it undertakes. Therefore, the company needs fund to make payments to those parties that are collected from the company's fund collection (ujrah or fee). Ujrah fund (fee) is not including the needs of participants to make the company spend the company's fund to meet these costs.

If the commission fee is high, then the company requires a high cost which causes the proportion of tabarru' fund will be lower. Ideally, commission fees negatively affect the proportion of tabarru' fund. This study found no evidence of that. In practice, sharia life insurance companies use insurance agents to market their products, so it requires a fee. The greater the proportion of tabarru' fund requires high commission fees as well, since insurance agents are given incentives based on their ability to gain participants. The results of this study are inconsistent with the results of Purwacaroko and Suprayogi research (2016) which states that the ideal composition of tabarru'-ujrah fund is influenced by exogenous variables (internal) ie the company's (marketing fee). It is also not in line with the results of research Puspitasari (2016) which states that the variable cost of commission into factors that affect the proportion of tabarru' fund in Sharia general insurance companies.

\section{The Influence of Administrative and General Expenses on Tabarru' Fund}

The results show that administrative and general expense variables partially do not negatively affect the proportion of tabarru' fund in sharia life insurance companies and sharia units of life insurance companies registered in 
the Financial Services Authority 2012 to 2016. Thus, the administrative and general burden is not a determinant proportion of tabarru' fund in sharia life insurance companies and sharia unit life insurance companies in the future. Hypothesis 4 states that administrative and general expense variables negatively affect the proportion of tabarru' fund, but the results of this study indicate that administrative and general expense variables positively influence. Ideally, administrative and general expenses negatively affect the proportion of tabarru' fund, meaning if the proportion of tabarru' fund increases, the administrative and general expenses decrease.

Administrative and general expenses are among the components paid by corporate fund. Company fund (ujrah or fee) are determined after the proportion of tabarru' fund has been determined, because the main principle is to help and in accordance with the ethics of sharia business. In this study it was found that the administrative and general expenses had a positive effect, indicating that if the proportion of the tabarru' fund increased, the administrative and general expenses also increased.

This may be because if the larger tabarru (indicates the number of participants), the greater the burden to manage the participants'fund. In the study period found the proportion of administrative and general expenses reached the highest value with an average value of $206.60 \%$. This proves that the company has a large portion of its operations. Each company has a different strategy in terms of business management, but for the internal management of the company in terms of employees for example is required in accordance with government regulations on workers who provide salary according to UMR. However, besides that the determination of decent compensation also affects the performance of employees and it affects the continuity of the company. This is in line with the results of research Pratama et al (2015) stating that the compensation effect on employee performance with more dominant financial compensation at PT. Asuransi Jiwasraya Persero Regional Office Malang.

The results of this study are inconsistent with Purwacaroko and Suprayogi research (2016). Itstated that the ideal composition of tabarru'-ujrah 
fund is influenced by internal exogenous variables. It is inconsistent with the results of the Puspitasari (2016) study which states that administrative and general expense variables are the factors affecting the proportion of tabarru' fund in sharia general insurance companies.

This study has some limitations during the research process and needs to be improved by further investigators who will discuss similar research. The limitation of this research, that is in this research happened autocorrelation, so it needed improvement to get estimation model which fulfill BLUE (Best Linear Unbiased Estimator) criteria. On the other hand, this research can not be interpreted as actually because the data is assumed to be normal distribution based on Central Limit theorem. In addition, in this study incorporates data of sharia life insurance companies and Islamic sharia unit companies in data processing. There are companies that have not implemented sharia thoroughly in its operations, so it is likely to be the cause there are differences in determinants of sharia life insurance companies and sharia unit life insurance companies.

\section{Conclusion}

Based on the data analysis and discussion it can be concluded that: (1) Claims have a positive effect on the proportion of tabarru' fund on family takaful, (2) Retakaful do not affect the proportion of tabarru' fund in family takaful, (3) commission fees do not affect the proportion of tabarru' fund in family takaful, and (4) General and administrative expenses do not affect the proportion of tabarru' fund in family takaful in Indonesia.

\section{References}

Ismail, M. (2013). Determinants of Financial Performance: The Case of General Takaful and Insurance Companies in Malaysia. International Review of Business Research Papers, 9(6), pp. 111-130.

Maksum, M.(2011). Pertumbuhan Asuransi Syariah di Dunia dan Indonesia. Jurnal Al-Iqtishad, 3(2), pp. 35-48.

Mardani.(2015). Aspek Hukum Lembaga Keuangan Syariah di Indonesia Edisi Pertama. Jakarta: Prenadamedia Group. 
Otoritas Jasa Keuangan.(2016). Statistik Perasuransian Indonesia tahun 2016. <http://www.ojk.go.id/id/kanal/iknb/data-dan statistik/asuransi/Pages/Statistik-Perasuransian-Indonesia--2016.aspx\#>

Pratama, S.A.,Hakam, M.S., and Nurtjahjono, G.E.(2015). Pengaruh Kompensasi terhadap Kinerja Karyawan (Studi Kasus Karyawan PT. Asuransi Jiwasraya Persero Regional Office Malang). Jurnal Administrasi Bisnis, 25(1), pp. 1-8.

Purwocaroko, B. and Suprayogi, N. (2016). Analisis Komposisi Ideal Dana Tabarru'Metode Dynamic Financial Analysis Perusahaan Asuransi Jiwa Syariah Di Indonesia. Jurnal Ekonomi Syariah Teori dan Terapan, 3(2), pp.158-172.

Puspitasari, N. (2011a). Manajemen Keuangan dan Strategi Perusahaan Asuransi Umum Syariah di Indonesia. Jurnal Manajemen, 5(3), pp. 262275.

Puspitasari, N. (2011b). Analisis Keuangan Dinamis Pada Manajemen KeuanganBisnis Asuransi Umum Syariah. Jurnal Manajemen Teknologi, 10(2), pp. 127-144.

Rahim, F.A., and Amin, H. (2011). Determinants of Islamic Insurance Acceptence: an Empirical Analysis. International Journal of Business and Society, 12(2), pp. 37-54.

Rahman, A.A., and Mohammad, S. (2010). Analysis of Tabarru' Principle in Takaful Contract: Malaysian Experience. Proceedings of 2010 International Conference on Humanities Historical and Social Sciencies. ISBN: 978-1-84626025-4. Singapore, 26-28 February 2010.

Sumanto, A.E., Priarto, E., Zamachsyari, M., Trihadi, P., Asmuri, R., Maulan, R. (2009). Solusi Berasuransi: Lebih Indah dengan Syariah. Bandung: PT Salamadani Pustaka Semesta.

Tanata, Wiko H. (2015). Membangun Personal Wealth: Menuju Masa Depan Lebih Terencana.Jakarta: PT Elex Media Komputindo. 